\title{
Differential visual depth discrimination of hooded as compared to albino rats'
}

\begin{abstract}
PHILIP W. DAVIDSON and RICHARD D. WALK, Program in Cognitive and Perceptual Development, The George Washington University, Washington, D.C. 20006
\end{abstract}

Hooded and albino rats were compared with each other on the visual cliff when the deep side was varied in its distance below the glass. The two species both discriminated depth and did not differ from each other when the deep side was 10 in. below the glass. Hooded animals chose the shallow side over the deep side when the deep side was 4 in. below the glass. Albino animals had chance performance when the deep side was 4 in. or 6 in. below the glass, but they showed a significant preference for the shallow side at $8 \mathrm{in}$. of differential visual depth.

A comparison of the visual depth perception of hooded and albino animals requires manipulation of visual cues, holding other factors as constant as possible. Two studies, Russell (1932) and Greenhut (1954), meet this criterion. Both showed much worse depth perception in the albino animal. Russell used a jumping stand technique to measure force of jump at various distances and found that the albino required a larger increase in distance before an increase in force of jump could be measured. Greenhut used a modified Howard-Dolman apparatus and found that albino animals were much worse than hooded animals in discriminating near from far wooden pegs.

Several studies have compared the depth perception of albino and hooded rats on the visual cliff, but none have varied visual depth alone. Walk \& Gibson (1961) found that albino and hooded rats showed equal preference for the shallow side of the visual cliff when the center board height was 4 in., the deep side was $10 \mathrm{in}$. below the glass, and a definite textured pattern was used on both the shallow and deep sides. Studies with a lower center board (e.g., 3 in., Routtenberg \& Glickman, 1964; 2 in., O'Sullivan \& Spear, 1964) have shown that albino animals are more likely to descend to the deep side, manifesting poorer depth perception. But Schiffman, Beer, Koenig, \& Clody (1967) found that the lower the centerboard the more likely the animal is to descend to the deep side. One could interpret the Routtenberg and Glickman or the O'Sullivan and Spear studies as simply showing a greater reliance on tactual cues by the albino animal when the cen terboard height is low. This would not be surprising in light of the inferior visual acuity of the albino as compared to the hooded rat (Lashley, 1930; Hermann, 1958).

The present study varied depth of the deep side as it compared albino and hooded animals at several visual depths. The method devised by Booher \& Walk (1968) was used to study the differential visual depth of the two species. The differential visual depth threshold of the hooded rat was known from the Booher and Walk study to be at about $3 \frac{1}{2}-4$ in.; the deep side must be about 4 in. below the glass before the hooded animal definitely descends to the shallow side reliably in preference to the deep side. The present study had to replicate the Booher and Walk results for the hooded animal and also the Walk and Gibson results, which used a 10-in. visual depth, where albino and hooded animals were found to be similar in their preference for the shallow side. With the replication of these results one would not expect good visual cliff performance by the albino animal at 4 -in. visual depth, the threshold for the hooded Ss. However, if the albino Ss are at a chance level at 4-in. visual depth, a further probe can be made until a differential depth threshold for the albino animal is reached. This should be, presumably, when the deep side is somewhere between 10 in. and 4 in. below the glass.

\section{SUBJECTS}

The Ss were 61 Long-Evans hooded and 121 SpragueDawley albino rats about five months old. Each sample had approximately equal numbers of males and females. All Ss were housed in group cages, segregated according to both species and sex.

\section{APPARATUS}

The visual cliff described and illustrated by Booher \& Walk (1968) was used. This apparatus permits variation of the visual depth (e.g., distance beneath the glass) of the deep side. Both shallow (pattern directly under glass) and deep (pattern at varied distances below glass) sides were covered with 1-in. red and white checked gingham cloth and illuminated from below. The centerboard consisted of an aluminum ice tray 17-7/8 $\mathrm{x}$ $3-5 / 8 \times 1-5 / 8$, supported by three $17-7 / 8 \times 3-5 / 8 \times 13 / 16-i n$. wooden boards. The total height of this centerboard from the glass surface was 4 in. The aluminum tray could either be filled with water and frozen, or remain empty and inverted.

\section{PROCEDURE}

Three separate experiments were conducted. Twenty-four Ss of each species were used in Experiment 1, 37 of each species in Experiment 2, and 60 albino Ss in Experiment 3.

Experiments 1 and 2 used differential visual depths of 10 in. and 4 in., i.e., the deep side was either 10 in. or 4 in. below the glass, the shallow side pattern always directly under the glass. Each $S$ was given two trials, Trial 1 with one differential visual depth and Trial 2 with the other depth. The Ss were run in groups of six, half hooded and half albino. After animals of each group had completed Trial 1, they were immediately given Trial 2. The Trial 1 visual depth (10 in. or $4 \mathrm{in}$.), the position of the deep side (east or west of the centerboard), and the end of the centerboard on which $S$ was placed (north facing south or south facing north) were all counterbalanced. After $S$ was placed on the centerboard, side and latency of descent were recorded. Animals which failed to descend within $3 \mathrm{~min}$ were removed from the centerboard and scored as "no descent."

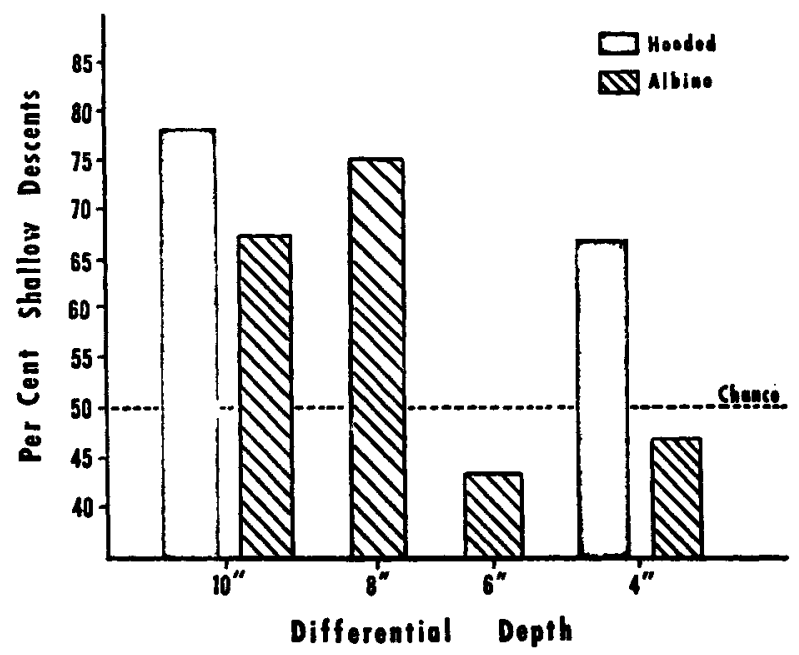

Fig. 1. Combined results of the three experiments to show performance of hooded and albino animals at each level of visual depth. 
Table 1

Performance of Hooded and Albino Rats in the Three Experiments

\begin{tabular}{|c|c|c|c|c|c|}
\hline $\begin{array}{l}\text { Visual } \\
\text { Depth }\end{array}$ & Species & Shall & $\begin{array}{l}\text { Descen } \\
\text { Deep }\end{array}$ & No Descent & $z(S$ vs $D)$ \\
\hline \multicolumn{6}{|c|}{ Experiment 1} \\
\hline $10 \mathrm{in.}$ & $\begin{array}{l}\text { Hooded } \\
\text { Albino }\end{array}$ & $\begin{array}{l}16 \\
13\end{array}$ & $\begin{array}{l}7 \\
6\end{array}$ & $\begin{array}{l}1 \\
5\end{array}$ & $\begin{array}{l}1.668^{*} \\
1.376\end{array}$ \\
\hline $4 \mathrm{in.}$ & $\begin{array}{l}\text { Hooded } \\
\text { Albino }\end{array}$ & $\begin{array}{r}15 \\
9\end{array}$ & $\begin{array}{r}8 \\
11\end{array}$ & $\begin{array}{l}1 \\
4\end{array}$ & $\begin{array}{r}1.251 \\
-0.224\end{array}$ \\
\hline \multicolumn{6}{|c|}{ Experiment 2} \\
\hline $10 \mathrm{in.}$ & $\begin{array}{l}\text { Hooded } \\
\text { Albino }\end{array}$ & $\begin{array}{l}24 \\
18\end{array}$ & $\begin{array}{l}4 \\
9\end{array}$ & $\begin{array}{r}9 \\
10\end{array}$ & $\begin{array}{l}3.591^{* *} \\
1.540\end{array}$ \\
\hline 4 in. & $\begin{array}{l}\text { Hooded } \\
\text { Albino }\end{array}$ & $\begin{array}{l}16 \\
14\end{array}$ & $\begin{array}{r}8 \\
15\end{array}$ & $\begin{array}{r}13 \\
8\end{array}$ & $\begin{array}{r}1.429 \\
-0.185\end{array}$ \\
\hline \multicolumn{6}{|c|}{ Experiment 3} \\
\hline $\begin{array}{l}8 \text { in. } \\
6 \text { in. }\end{array}$ & $\begin{array}{l}\text { Albino } \\
\text { Albino }\end{array}$ & $\begin{array}{l}21 \\
12\end{array}$ & $\begin{array}{r}7 \\
16\end{array}$ & $\begin{array}{l}2 \\
2\end{array}$ & $\begin{array}{l}2.462^{* * *} \\
-0.568\end{array}$ \\
\hline
\end{tabular}

${ }^{*} p<.05$ (one-tailed); ${ }^{* *} p<.01$ (one-tailed); ${ }^{* * *} p<.02$ (two-tailed)

Experiments 1 and 2 differed with respect to (1) level of apparent illumination of the shallow and deep sides, and (2) composition of the centerboard. The apparent illumination was adjusted by a powerstat (Superior Electric Co.) to approximately $18 \mathrm{ft}-\mathrm{c}$ on both sides (about a reading of 7.5 on a Weston Master $\mathrm{V}$ lightmeter) in Experiment 1, and approximately $2 \mathrm{ft}-\mathrm{c}$ ( 4.2 meter reading) in Experiment 2 . For Experiment 1, the ice tray was filled with water to within $1 / 2$ in. of the top and frozen; the Ss were placed directly on the frozen surface. In Experiment 2 the tray was empty, inverted, and at room temperature.

Experiment 3 presented albino Ss with differential visual depths of 8 in. and 6 in. Pilot experimentation indicated that depth might interact with repeated testing when visual depths differing by as small an amount as $2 \mathrm{in}$. are investigated. Hence, Ss in Experiment 3 were given only one trial. The level of illumination and centerboard for this experiment were identical to those of Experiment 2. The experimental procedure and counterbalancing were identical to those of the first two experiments.

During all experiments, the test room lights remained off and the only illumination came from beneath the visual cliff apparatus.

\section{RESULTS}

Figure 1 shows the combined results of Experiments 1 and 2, and of Experiment 3. Experiments 1 and 2 (combined) showed both hooded and albino Ss preferred the shallow side at $10 \mathrm{in}$. of differential visual depth [ $\mathrm{z}$ (hooded) $=3.92$, $\mathrm{p}<0.01 ; \mathrm{z}$ (albino) $=2.21, \mathrm{p}<0.05$ ], while only the hooded rats preferred the shallow side at a deep side depth of 4 in. $(z=2.02, p<0.05)$. While Experiments 1 and 2 indicated chance performance for the albino Ss at 4 in. $(z=-0.29)$, Experiment 3 showed that albinos also fail to show a preference at 6 in. $(z=-0.568)$. It was not until the differential visual depth was 8 in. that a significant shallow-side preference appeared for albinos $(\mathrm{z}=2.462$, $\mathrm{p}<0.02$, two-tailed).

Table 1 presents the separate results of the three experiments. Experiments 1 and 2 did not differ significantly from each other with respect to frequency of shallow-side descents. For Experiments 1 and 2 combined, hooded and albino animals did not differ from each other at the 10-in. depth $\left(x^{2}=0.99\right)$, but the hooded were better at the 4 in. depth $\left(x^{2}=2.80, p<.05\right.$, one-tailed $)$. Experiments 1 and 2 did differ slightly in the number of no descents with fewer Ss descending from the centerboard in Experiment 2, both at 10 in. $\left(\chi^{2}=3.35, p<0.10\right)$ and at 4 in. $\left(\chi^{2}=5.68, p<0.05\right)$.

The overall median latencies for Experiments 1, 2, and 3 did not differ significantly (Experiment 1. $13 \mathrm{sec}$; Experiment 2.
$16 \mathrm{sec}$; Experiment 3, $15 \mathrm{sec}$ ) nor were there any significant differences between latencies of hooded Ss and albino Ss (hooded, $17 \mathrm{sec}$; albinos, $14 \mathrm{sec}$ ).

\section{DISCUSSION}

We have varied visual depth alone to show that the albino rat is inferior to the hooded animal in differential visual depth discrimination. The two species do not differ at definite visual depths, but the albino animal descends in a chance fashion to the shallow side at 4 in. or 6 in. of visual depth on the deep side while the hooded animal discriminates visual depths of 4 in.

Our experiment agrees with the two other experiments where an approximation to a threshold for depth discrimination was secured, that of Russell (1932) and Greenhut (1954), both of which also showed higher thresholds for the albino animals. These experiments used different techniques and are not directly comparable to ours. The Russell (1932) experiment showed that the hooded animals seemed to exert greater force toward pedestals at incremental distances of about $1-2 \mathrm{~cm}$ while albino animals required about $2-4 \mathrm{~cm}$ of additional distance for a difference in exerted force to be measured. Greenhut (1954) used pegs and found a standard deviation of $4.1 \mathrm{in}$. for hooded animals and $7.3 \mathrm{in}$. for albino Ss in choice of a nearer or farther peg when the "standard" was 10 in. away. Booher \& Walk (1968) found a differential depth threshold of $3-3 \frac{1}{2}$ in. for hooded animals, though the 4-in. differentia! depth was much easier to replicate (Walk \& Bond, 1968).

Thus, all experiments on visual depth, despite very different techniques, show that the threshold for the discrimination of visual depth in the albino animal is roughly twice as high as that of the hooded. Similarly, visual acuity of the albino animal is about half that of the hooded animal [ $20 \mathrm{vs} 40 \mathrm{sec}$ of visual arc (Lashley, 1930; Hermann, 1958)] .

Experiments using lower centerboard heights (Routtenberg \& Glickman, 1964; O'Sullivan \& Spear, 1964) that have shown poorer performance by albino as compared to hooded Ss are undoubtedly tapping the poorer visual depth perception of the albino animal. However, only when visual cues alone are varied, and other cues kept constant, can some quantitative assessment of the comparative visual depth perception of the two species be made.

\section{REFERENCES}

BOOHER, H. R., \& WALK, R. D. Apparatus for the differential visual depth threshold and its determination in the hooded rat. Psychonomic Science, $1968,12,187 \cdot 188$.

GREENHUT, A. M. Visual distance discrimination in the rat. Journal of Experimental Psychology, 1954, 47, 148-152.

HERMANN, G. Beiträge zur Physiologie des Rattenauges. Zeitschrift für Tierpsychologie, 1958, 15, 462-518.

LASHLEY, K. S. The mechanism of vision: III. The comparative visual acuity of pigmented and albino rats. Journal of Genetic Psychology, $1930,37,481-484$.

O'SULLIVAN, O. J., \& SPEAR, N. E. Comparison of hooded and albino rats on the visual cliff. Psychonomic Science, 1964, 1, 87-88.

ROUTTENBERG, A., \& GLICKMAN, S. E. Visual cliff behavior in albino and hooded rats. Journal of Comparative \& Physiological Psychology, 1964, 58, 140-142.

RUSSELL, J. T. Depth discrimination in the rat. Journal of Genetic Psychology, 1932, 40, 136-159.

SCHIFFMAN, H. R., BEER, B., KOENIG, A., \& CLODY, D. E. Comparison of tactual and visual cues on the visual cliff. Psychonomic Science, $1967,9,437-438$.

WALK, R. D., \& BOND, E. K. Deficit in depth perception of 90-day-old dark-reared rats. Psychonomic Science, 1968, 10, 383-384.

WALK, R. D., \& GIBSON, E. J. A comparative and analytical study of visual depth perception. Psychological Monographs, 1961, 75, No. 15 (Whole No. 519).

NOTE

1. This research was supported by National Institutes of Health Grant 1-T01-HD 00203-02 and National Science Foundation Grant GB-7937 to the second author. We wish to thank Epp Miller, Edward Mahn, and Richard Maurice for helping in the collection of data. 